УДК $316.34,305-055.2$

Nwaoduh E.O., PhD. Student, Social Structures and Social Relation Department Taras Shevchenko National University of Kyiv, 60, Volodymyrska Str., Kyiv, 01033, Ukraine, e-mail: eberenwaoduh@gmail.com

\title{
FEMINIZATION OF POVERTY IN UKRAINE: BACKGROUND, CAUSES AND EFFECTS
}

This paper $x$-rays the presence and nature of feminization of poverty in Ukraine, exposing its background, causes and effects. Feminization of poverty which is the process of the female gender being more vulnerable to poverty is mainly driven by factors such as gender inequalities in making decisions; in the labour market, disparities in earnings and the roles of women in Ukrainian society. Women fared better during the Soviet era in Ukraine because everybody had to work. Nevertheless, despite the fact that they were employed in the public sector, they were also saddle with the responsibility of handling domestic affairs. This dual function made them underperform in the public sector, which yielded money unlike the domestic sector, which was demanding and unpaid for. The years following the collapse of the USSR were marked by changes, which had negative effects of exclusion and lack of women in the country. The impact of women's child bearing roles and domestic responsibilities has made them suffer more then men from the general hardship and worsening economic situation. Some causes were identified under the following subtopics: Economic/Labour, Political/Decision making, Family composition/Demography and Choice/Attitude (Agency), while the effects include: forceful exit from labour market, Inadequate nutrition, inadequate access to proper medical care, low participation in contesting for electoral positions, few women in leadership/decision making positions in public and private sectors especially big businesses. Recommendations which include more participation in political activities and aiming at high political positions, reduction in segregation in the labour market by ensuring gender balance, engagement of both male and female partners in domestic activities and better wage and position bargaining and so on were made.

Keywords: feminization of poverty, social exclusion, gender inequality, segregation.

Introduction. Poverty and issues related to it were typically studied from the points of social class, race or ethnicity. Social scientists today are increasingly concerned with the social and demographic dimensions of poverty with increasing concern on women living at or below the poverty line; having low access to resources such as time, food, participation in decision making; availability of access: to health care, gainful employment and political positions among other resources, what categories are at higher risks and why.

Feminization of poverty refers to the process of the females being more susceptible to poverty. In many societies, poverty has been associated with women. This is because a lot of women are not involved in high income generating activities. It has been witnessed that there are only a few women who form part of the most popular income generating activities for instance politics. Men have taken over governments, big companies as well as other institutions that are ranked highest in terms of their income [1]. As a result, women have been left to engage in some activities that generate only enough income to cater for their basic needs and in most cases they are unable to meet them all.

The former Director of the Women and Poverty Project of Wider Opportunities for Women Diana Pearce coined the term "feminization of poverty" in 1976 when observed that two thirds of the poor in the U.S. were women over the age of 16 and that women's

(C) Nwaoduh E.O., 2017 
economic status had declined from 1950 to the mid-1970s. She stated that feminization of poverty was due to lack of government support for the nation's growing number of predominately white divorced single women, hence, female-headed households had formed a larger percentage of the poor even though more women had entered the labour market [2].

This paper aims to find out how feminization of poverty exists in Ukraine; by digging into its causes and finding out its effects and making recommendations based on the findings.

Feminization of poverty is not a problem peculiar to Ukraine or any single country; it is a global problem that concerns different countries at different rates and in different forms. In Ukraine, this process and its studies seem to be recent. According to Rudnichenko in an article on "Being a woman in Ukraine", during the Soviet times, women were viewed as mothers and workers, combining the two functions. The Soviet constitution of 1936 and 1977 declared equal rights for men and women but any unbiased study immediately showed that the constitutions were biased as far as women were concerned on the deeply ingrained patriarchal stereotype - the men were treated as the driving force and model for society, whereas women were relegated to being solely homemakers and caretakers of the family. This Soviet declaration of equality made it unnecessary for gendered inequality studies at that time [3].

According to Tolstokorova, in a research on Multiple Marginalities: Gender dimension of rural poverty, unemployment and labour migration in Ukraine, the years following the collapse of the USSR in 1991 were marked by multiple transformations, a hallmark of which was a changing attitude towards the role and status of women in society, accompanied by democratization of gender relations in all domains of life. Although increasing poverty, unemployment and declining social welfare resultant from the transition to capitalism affected both genders, the impact on women was more dramatic because of their reproductive roles and family responsibilities [4].

This transition period in Ukraine gave rise to an increased gender inequality in the areas of poverty and social exclusion. Feminization of poverty in Ukraine is mainly triggered by factors such as gender inequalities in the labour market, wage gap and women's maternal role in the society. Women in Ukrainehave equal constitutional rights as men in the economic, political, cultural and social fields, as well as in the family, but despite all these, in practice they do not enjoy this equality as they, for instance, receive lower salaries and have limited opportunity for career advancement. This makes them more prone to be being poor than men in Ukraine and also it makes women headed households suffer more lack and poverty than the male headed households. In the study "The Gender Gap in Incomes and Poverty Feminization in Ukraine", the present Ukrainian society is characterized by high levels of inequality, related to: population incomes, access to basic social services, health status and life expectancy, living conditions and quality of life and access to labour market. She further opines that "It is rather difficult to assess the phenomenon of poverty feminization in Ukraine, as the national statistics system does not provide complete information on income distribution within households by gender of household members [5]. This also poses a challenge to data sourcing of this paper. 
Traditional stereotypes, which tend to reduce women to their motherhood nature and activities are still strongly held unto in the present day Ukraine and reproductive labour is predominantly done by women and explained stereotypically as "traditional" women's "duty"... The only type of household work remaining a "male" prerogative in most domestic households consists of minor repair [6, p. 212-214]. This historical antecedent engenders disproportion in social, economic and private life. Although both genders to have similar chances of self-actualization in society since educational and professional training are equal and there is no discrimination in legislation, some of the real problems that encourage feminization of poverty are: underrepresentation of women in politics and at all levels of decision-making; the fact that women get less paid and occupy lower positions than men with the same education (vertical segregation); the concentration of women in occupations of lower income (horizontal segregation) due to gendered education, an accelerated "feminization" of poverty and dual employment of women in paid jobs and unpaid jobs in the home economy where they face double inequality [6, p. 216].

The Labour laws have established legal equality between men and women; including them having equal pay for equal work. It is however observable that industries dominated by female workers have the lowest wages and have higher chances of being affected by wage arrears. The Labour code set the retirement age for women at 55 and for men at 60 before 2012. By 2021 the government decided to increase the retirement age of women to 60 . The reform also increased the contribution period required for the minimum pension by 5 years for both sexes [7]. This on its own makes the same women who had lower wages retire earlier to be left with meager pension since pension is determined by contributions made based on the position attained while in active service and the length of the service.

Reports also exist of some employers refusing to hire younger women who are likely to become pregnant or women over 35 [8]. This is supposedly to improve "effectiveness and efficiency" as pregnant women require a lot of rest, hospital time and maternity leave with pay and more time for child care afterwards. Based on the mentioned, "only a few women hold top managerial positions in the government or in state-owned or private industry" [9]. Taking cognizance of the percentage of women population in Ukraine, their equal participation in all spheres of life is crucial as it will create a balance and maintain stable development of the society leading to more development.

Since after the fall of USSR, some of the related studies cited above, have discussed certain aspects of feminization of poverty in Ukraine including Grushetsky and Kharchenko who studied poverty, gender and coping strategies in Ukraine [10]. A lot of these researches have tended to study feminization of poverty from a major cause or effect, whilethis study tries to bring to bare it causes both economic and non-economic, its effects and possible ways to reduce the problem. More light could be shed on this topic by other researches in the areas of how the current economic problems resultant from the Ukraine-Russian crises has worsened women's susceptibility to poverty and life chances in Ukraine.

This research is basically descriptive and uses a combination of statistical and sociological data obtained from surveys, previous studies and texts. These data provide information about current causes of feminization of poverty in Ukraine. 
The Structuration theory propounded by Anthony Giddens in his book "The Constitution of Society. Outline of the Theory of Structuration" (1984) explained that both the structure of society and human agency are accountable for how things work within society [11], proffers a sound explanation for better understanding of feminization of poverty in Ukraine due to its recognition of "duality of structure" [12].

Here, social structures (traditions, institutions, moral codes, and established ways of doing things) which influence actions of members of society are viewed as products of individual action that are sustained or changed (when people start to ignore them, replace them, or reproduce them differently).

Feminization of poverty exists in Ukraine due to absence of structural opportunities such as well-paid employment, lower presentation of women in political and other decision making positions among others, as well as women's inactions due to accepting societal stereotypes of what they should do and be. Their inability to negotiate for better paid jobs, sharing of domestic responsibilities and accepting the status quo has also resulted in their vulnerability.

Major causes. Feminization of poverty in Ukraine implies monetary inequality as well as political, social, economic and cultural exclusions. Some of the underlying causes of feminization of poverty in Ukraine will be discussed under the following subtopics: Economic/labour, Political/decision making, family composition/Demography and Choice/Attitude (Agency).

Economic/Labour Factor. Inequality and exclusion at the labour market are seen to be the causes of feminization of poverty in Ukraine. The transition has affected the labour market in several ways, and the following gender-related trends can be observed in the Ukrainian labour markets: Increase in female unemployment levels and a decline of women participation in the labour market; Occupational segregation and women concentration in low paid sectors and jobs; ... [14]. Thesetrends are still present. Chepurko further stated that women are also the first to experience the negative consequences of the economic crisis, including cutbacks in social packages, dismissals, working time reductions or wage cuts [15]. As at 2015 the rate of employment of women was $51.7 \%$ and men $62.2 \%$ according to State Statistics Service of Ukraine [16]. Labour market exclusion exists as segregations in the areas of employment opportunities, employment forms and status, access to decent labour, prestigious and well-paid positions available to women. The nature of participation by women in the labour market determines how susceptible to poverty they will be. Therefore when vertical and horizontal occupational segregation exists, women are more liable to poverty.

"About $50 \%$ of all enterprises without employees are woman owned. Enterprises with 1 to 5 employees are $27 \%$ woman owned. Enterprises with less than 50 employees are $30 \%$ woman owned. These numbers are similar to those in other Western economies. Women tend to lead small businesses in retail, wholesale trade, and catering" [17]. In Ukraine, women owned 20$22 \%$ of small and medium enterprises and only $2 \%$ of big ones in 2013 [18].

In 2015, according to State Statistics Service of Ukraine [19] $30.8 \%$ of men were economically inactive while $43.8 \%$ of women were. This situation is direr in the rural areas, 
Nwaoduh E.O.

where $71 \%$ of men are employed compared to $59 \%$ of women [4]. In 2016, a total of $61.6 \%$ of men between 15-70 years were employed while $51.6 \%$ of women were employed [20].These discrepancies leave woman in a disadvantaged position.

Access to economic resources is determined by wages, other income sources and distribution of resources within households. A large gender gap exists in the income level in Ukraine. Women are generally paid less than men. It is estimated that the salaries of women amount to $70 \%$ of men's because they engage in different professions at different levels. According to State Statistics Service of Ukraine women received lower wages in 2016 than men in all the listed activity types except: libraries, archives, museums and other cultural activities, where in the first half of the year, they received about $\$ 144$ and the men $\$ 138$ and in administrative and support service activities - about $\$ 160$ and $\$ 155$ respectively. This margin is not as wide as is the case between women and men in areas such as professional, scientific and technical activities- about $\$ 279$ and $\$ 331$; agriculture, forestry and fishing $\$ 175$ and $\$ 233$ respectively. The gap between men and women is more than $\$ 40$ in most areas (at $24 \mathrm{UAH}-\$ 1$ ) [21]. This is achieved through professional segregation where certain jobs and tasks are dominated by women and they collectively receive lower wages; a phenomenon referred to as the feminization of low paid jobs [6, p. 216]. Household Budget Survey of 2011 shows that women's average income is only $65.3 \%$ of the average income of men, i.e. about $\$ 140.3625$ against $\$ 215.025$ per month (at 8 UAH to \$1) [22]. Obviously, such significant differences in income level are unjustified, considering the equal educational and qualification potential of women and men [5, p. 7].

Gender disproportions in the material welfare of the population are reflected not just in women's lower incomes, but also in differences in the sources of incomes. In comparing income source structures between men and women, gender inequality in the labour market is evident. Women's incomes, to a great extent, are from non-labour sources (pensions, stipends and benefits), whereas the share of men's employment income, including both remuneration and income from entrepreneurial and self-employed activities, is significantly higher. Moreover, the later sources of income contribute the most to the gender gap: i.e. women's average income from entrepreneurial activities is only $34.3 \%$ of that of men, and women's average income from self-employment is $39.5 \%$ of that of men [5]. United Nations Ukraine document on gender equality states that women make a majority in care and unpaid domestic work, with limited control over assets and productive resources. Their unaccounted/unpaid domestic work which women engage in, further widens the gender income gap between men and women. This disparity in income is also a contributing factor to the feminization of poverty in Ukraine [19].

Political/Decision Making Factors. The case of low participation in decision making by women in Ukraine is engendered by their world view; the pressures of family life and poverty. Women's low involvement in political processes, state governing and top management of economic organizations at various levels has been a factor responsible for women's vulnerability to poverty. Their low presence at top decision making levels prevents them from initiating laws, policies and making special provisions and decisions that benefit, protect and enhance their life chances in all spheres as a group, especially considering the 
roles they play in the society and also ensuring the implementation and compliance of laws and policies, thereby de-feminising poverty.

Following the 2014 parliamentary elections, the Verkhovna Rada continued to be an almost totally male-dominated body, consisting of only $12 \%$ of women. Since independence, Ukraine has shown little improvement in increasing the number of women in Parliament that could be explained by a number of factors on the societal, political and individual levels. Women have less money and fewer social networks to work with, and the stereotype of politics as a dirty business further justifies patriarchal notions of blocking them out. Ukrainian women are supposed to fulfill two main roles - to be beautiful (in order to inspire men) and to be mothers (to provide reproductive resources and care for a nation). In this situation it is hard to perform other roles [6]. The current exclusion of Ukrainian women from decision making at the highest political and economic levels is inconsistent with high indicators of their participation in the lower levels of the public service sector.

The current crisis in Ukraine which began towards the end of 2013 due to the refusal to sign the agreement of association between Ukraine and the European Union by the previous President, led to the Euromaidan; the inferences of Russian Federation and annexation of the Crimea led to the unrest in some parts of Eastern Ukraine, which are not government controlled such as Donetsk and Luhansk regions. This Conflict has led to displacement of millions of people and worsened economic situation generally. According to Gienger "in a nation of 44 million people, about 2.6 million Ukrainians have fled the war in the East initiated by Russian-backed separatists, and more than 1.4 million of them are still in the country. About two-thirds find refuge with friends, family or others who've been displaced, and humanitarian agencies are bracing for the long haul. ... More than 8,000 people have died since the war began in April 2014". Most of those who lost their lives are men and this is further increases female headed households and poverty due to low incomes of the women. Gienger further gathered that, the impact of the war and displacements are profound. ... Fully two-thirds of those displaced in Ukraine are women, and the economic crisis has thwarted their ability to get jobs to earn a living if they are the only source of income while men are deployed [23].

In 2015, a sharp contraction in economic activity and high inflation are estimated to have almost doubled the moderate poverty rate from $3.3 \%$ in 2014 to $5.8 \%$ in $2015 \ldots$ revenues are down and expenditures are up in 2016, mostly due to lower social security contributions (SSC). The crisis and war in Ukraine for the past two years has made standard of living drop terribly [24].

Family Composition/Demography. There is a large gender gap of 12 years in terms of average life expectancy of the population (average life expectancy at birth is 74 years for women against 62 years for men), which remains a significant indication of inequality. When people get old and retire, they engage in less financially productive activities and since women in Ukraine live longer, they are more exposed to low resources and consequently poverty. Gerasymenko supports this view by stating that ... socio-demographic population groups could be determined as poverty clusters or poverty profiles in Ukraine: ... elderly persons (in particular, households with at least one person aged 75+)...[5]. The genderrelated trends observed in the Ukrainian and Russian labour markets included poverty mostly 
among single elderly, or single mothers [14, p. 33]. According to demographic calculations of 2008, the probability of not living until 60 years of age was $39 \%$ for boys of 16 years of age against $14.5 \%$ for girls of the same age. The major component of this gap is made up of high mortality rate men of working age. This invariably will results in more single headed households who equally are more exposed to the cold hands of poverty. Feminization of poverty in Ukraine is high proportion among elderly women in the country. It is estimated that women comprise $60 \%$ of the total population of Ukrainians aged 55 and above [4]. The country has limited benefits for this age group such as pension, leaving them vulnerable to poverty. In rural Ukraine, old women are left to live alone with limited family support. Senior rural women who constitute a group at poverty risk primarily because many of them (40\%) live alone, without any family support. Sociological survey as of 1998 evidenced that only $6 \%$ of them received retirement allowances in due time, while $57 \%$ experienced chronic suspense in their delivery. It comes as no surprise, then, that $82 \%$ of senior farm women estimated their wellbeing as below average, low or very low, $19 \%$ - as very low and mere $1.3 \%$ - as above average [4, p. 6]. Poverty in Ukraine is highest among older people, children and people with disabilities. This illustrates why poverty in single mother households especially with disabled children and those with old women is highest $[10, p .6]$.

Single mothers and mothers with many children face greater poverty risks not only because of their vulnerable position on the labour market and scarce welfare benefits, but primarily because they bear the major burden of child care and maternal care expenses. Thus, the highest incidence of poverty are marked among such groups: single women with young children, especially mentally disabled- $70 \%$ of such households are headed by single mothers; single women caring for elderly family members $-90 \%$ of these households are headed by females; families with many children - by $80 \%$ are mother-headed [4, p. 5].

Choice/Attitude (Agency). Some women expose themselves to poverty by their actions and inactions of slothfulness; staying at home to cater for domestic needs; giving their domestic responsibility priority over formal labour market activities; settling for less in terms of pay and position; depending on social welfare/securities; getting constrained by stereotypes which ascribe weakness and second fiddle positions and roles to them; preferring to study the perceived easy and feminine courses. Women form more than three fourths of life science and health associate professionals; teaching professionals and associate professionals; personal and protective services workers; customer services clerks; office clerks [22]. Sectors which guarantee a higher wage (fuel industries, ferrous and coloured metals) have a low proportion of female labour and a large differential in wages between men and women whereas in sectors such as light industry, with one of the lowest wages, women dominate [13, p. 37]. In Ukrainian society, most of these occupational groups feature low prestige and recognition, and are pre-perceived as 'female' activities [25]. This shows that women choose to align themselves to certain categories of jobs.

The mass media, particularly, television and newspapers have laid a lot of emphasis on the maternal nature of women, thereby reinforcing the need for women to be good mothers and parents before any other thing. They have propagated the super woman and mother concept such that any woman not in conformity with this picture does not necessarily feel like a heroine. When women succeed and break new grounds, they are seen as strong women doing 
what men do; this strength is not usually associated with their femininity, but promotes masculinity. The media has helped maintain the social stereotypes which encourage women's dependence on paternity.... women should have men protecting and providing for them, they should bare and raise children to keep the society going. Martsenyuk et al support the above idea by stating that a significant problem is stability of stereotypes about the roles of men and women in society and family (which are spread through education and mass media). They further depict that during the Maidan protests of 2013-2014, the media, print and electronic resources played an active role in reinforcing gender based stereotypes [26, p. 8].

Gender discrimination is widespread in Ukraine. Gender norms are narrowly defined with traditional, patriarchal views and values reinforced by media and school curriculums. The ongoing conflict in Eastern Ukraine has deepened gender stereotypes that emphasize men as protectors and heroes and women as caring supporters, and limited women's engagement and involvement in conflict resolution [27].

Effects. Poverty has various manifestations, including lack of income and productive resources sufficient to ensure a sustainable livelihood; hunger and malnutrition; poor health; limited or lack of access to education and other basic services; increasing morbidity and mortality from illness; homelessness and inadequate housing; unsafe environments; and social discrimination and exclusion. It is also characterized by lack of participation in decision-making and in civil, social and cultural life [24].

The repercussion of women's higher vulnerability to poverty manifests harshly in several aspects of her life including those of her children and the country at large. The hardship it poses plays out in the under listed factors.

Exit from labour market. While the unemployment among men is somewhat higher than among women (7\% vs. $6 \%)$, discontinuation of the economic activity is more common among women [9]. According to ILO methodology in 2012, among the able-bodied Ukrainian women, the unemployment level is lower as compared to men (7.2\% against $8.9 \%$ accordingly); this level is also lower for all women in total making up 6.4\% against $8.5 \%$ among men. The 2013 data, however, evidences that more unemployed men were employed as compared to the unemployed women: 154,300 men against 116,200 women constituting about $43 \%$ of all individuals that were employed (calculated based on the employment of the unemployed by g0ender in 2013) [29]. While according to Rudenko in 2013, 55\% of the unemployed were women [30]. The lower wages ( $70 \%$ of men's) earned by women is losing value and as such can hardly afford to satisfy basic needs. According to Koriukalov "Devaluation of the national currency, decline of the economy, inflation, in particular, the increase of prices for housing utilities are creating risks of vulnerability and poverty for women, in particular single women [31]. Currently, women's exit from labour market is not unrelated to economic crises in Ukraine. The level of employment of IDP between 15-59 years was $78 \%$ before displacement, and now after displacement it is $48 \%$ women, $68 \%$ men [32]. Rudenko further states that "Among IDPs most are women with children who have lost their jobs". Women and children constitute two-third of 1.6 million of officially registered internally displaced people [30]. They face difficulties in exercising their economic and social rights: access to jobs...[18]. 
Low Participation in Leadership and Decision Making Process: this factor is both a cause and an effect of feminine susceptibility to poverty.Women'saccess to financial and other resources - such as political power is also very limited... possibly this must lead to a feminization of poverty [10]. As a result of low resources, only very few women are able to contest for politically elected positions especially at the higher level regional leaderships, parliament and presidency as evident from their representation in government which is the highest since independence. According to Martsenyuk, "As it was mentioned in the analysis of Global Gender Gap Report and other international data, political empowerment component is the most problematic one while speaking about gender equality implementation in different spheres of the Ukrainian society. Women have less resources and social networks to be successful competitors with their male colleagues [6, p. 218]; it has encouraged stereotypes that women unlike men are not good at political decision making. As a result few women are able to make it to leadership/decision making positions in political, public and private sectors and even in big businesses.

Inadequate Nutrition. Ukraine too has seen reduction in poverty and hunger as GDP increased since 2000. Yet significant inequality has left marginalized groups such as women, children and elderly vulnerable to hunger and poverty. Also unrest in Ukraine between 2013 and 2015 has reportedly contributed to food shortages in the country [33]. Poverty denies any individual access to adequate food [28]. Feminization of poverty therefore leads to inadequate access to food or monotonous feeding leading to malnutritionGlobal Gender Gap Report underweight and sickness. To be able to buy adequate food and have balanced nutrition, purchasing power is needed. When women are more susceptible to poverty, they end up also being more susceptible to not purchasing as much food as they need and in the proportions they need. They resort to cultivating the little they can and buying as much as they can afford. With higher cost of commodities in the current day Ukrainian market, older women and single mothers with children become the worst hit because demographically there are more older women than older men and they rely on their pension which is low and any other meager sources of income while having huge bill to pay where as single mothers have small support for their children and end up running their families with their sole income.

Poor access to proper health care. The Ukrainian government has done quite a lot to improve maternal health care.However, women's reproductive health remains poor for several reasons. There is low public awareness about reproductive health and rights. For many women, reproductive health services are inadequate, inaccessible, unaffordable, and of poor quality. According to the Ukrainian Institute of Gynecology and Obstetrics, $40 \%$ of Ukrainian women cannot carry out a normal pregnancy, and every sixth woman is infertile. Malnutrition and poverty increase health risks for women during and after pregnancy... [34, p. 31]. Women in poverty have reduced access to health care services and resources [35]. For any sick person to access good medical health care the person is required to have some money to pay hospital bills and/or buy medications. Women's higher chances of being poor translate to lesser access to good medical facilities. The public hospitals, which are cheap are not well equipped with modern facilities and usually have to make referrals for special or complex cases which require special attention. The fact is that most well equipped hospitals 
are located in urban centre and are very expensive to access, whereas most poor people who constitute the majority of the population live in suburban and rural areas.

Discussion of findings. This paper has explained feminization of poverty as a demographicdimension of poverty based on unequal gender susceptibility; giving its meaning and how the concept emerged. It has also treated the topic from the point of limitation of access to social resources as well as economic. The following information was gathered about feminization of poverty in Ukraine.

Feminization of poverty in Ukraine implies monetary inequality in the area of wage gap which is about $30 \%$ between men and women. There exists vertical and horizontal segregation in the labour market which reinforces wage gap. Politically, women are underrepresented especially at the highest levels of parliament and ministerial appointments. Women are socially and culturally expected to perform their maternal roles more than other roles and this is accompanied by various stereotypes and paternalistic propaganda which influences a lot of women's choices, attitudes and negotiation dispositions negatively and they result in poverty. The stereotypes that women are better at service and care jobs have also influenced their eventual location in the labour market (sector) [6]. It was found out from literature that, female headed families with two or more children and children with disabilities, and households headed by single old women are more likely to bear the brunt of poverty in Ukraine. The economic crises resultant of the political instability and ar situations in Ukraine since late 2013 have worsened the susceptibility of women to poverty as many businesses have closed down, their meager pay is unable to satisfy basic needs due to devaluation of currency and most of the people who have lost their lives are men who assisted women in providing for their families.

These causes have led to a lot of women out of the labour market (due to low pay, other job discriminations and family responsibilities); engage less in politics which requires political, economic and social capital which most women do not have (Martsenyuk is of the view that "Political life in the country is also perceived as rather "dirty games", not suitable for women. Women also face problems with solidarity and empowerment and this is reflected by the $12 \%$ of 450 deputies in the Parliament" [6, p. 218]) and put in more resources in the domestic sphere. Feminine poverty leaves poor women with inadequate food and most times monotony which affects their health and productivity. With inadequate money, accessing good medical services is very hard.

Recommendations. Based on the findings made, there are some steps to be taken: reduction in discrimination and segregation in the labour market by engaging both genders in non-stereotypical activities to ensure gender balance; better wage demand and negotiation by women; the engagement of both male and female partners in domestic activities to create more time for women's personal advancement; more participation in political activities at individual and group levels and aiming at high political positions are recommended to bridge the gender gap in poverty susceptibility and palliate this problem.

Conclusion. Like in most developing countries, gender inequality exists in Ukraine and some of the dimensions with which it does have been $\mathrm{x}$-rayed in this paper. Based on available information, it can be concluded that there is no gender discrimination when it comes to quality or access to education, but rather the types of jobs women engage in. The 
Nwaoduh E.O.

non-discrimination creates a better opportunity for Ukrainian women to achieve equality in all spheres of life if they delve more into the traditional male fields. Optimum use of this opportunity is yet to be achieved as certain groups of women (like the old and single mothers with children; many children and disabled children) are still more prone to poverty than the rest of the society. It is observed that higher vulnerability to poverty among women results from underemployment; vertical and horizontal segregation; working in the less profitable sectors of the economy, hence lower paying jobs and wage; low participation in politics and lower access to decisionmaking at top level, which deprives them from fostering legislations and programs that reduce their susceptibility, higher life expectancy, which leaves them alone in older ages, and single parenting which leaves them less resources, and the current crises in Ukraine has led to negative economic changes. These have led to untold hardship among more the vulnerable women and have created an inability to promulgate policies that are more women and children based and ensuring their full implementation.

Going by the structuration theory used as a framework for this paper, it can be seen that there are structural factors such as economic/labour market factors which lead to unemployment/underemployment and low wages for feminized jobs; political factors which results in low representation at top political positions, the war crises in some regions of Eastern Ukraine which has made life generally more difficult in Ukraine and agency factors such as choice of: economic activity to engage in, wage bargain, course of study, time invested in domestic activities, adhering to stereotypes which are responsible for and encourage feminization of poverty in Ukraine. These structural problems highlighted constrain women and thereby create room for them to make the choices they make. In turn, the choices the women make sustain and encourage the existing structure, which makes them more susceptible to poverty. This interconnection structure and agency perpetuates feminization of poverty. Women make choices based on the limited resources at their disposal while making a living. They thereby allow the structures of the society to be maintained. Feminization of poverty therefore, can be mitigated through various strategies such as increasing: participation of women in decision making processes such as their involvement in advisory roles in government, parliament and even the executive arm; their negotiating prowess at the labour market for better position and better pay and also in the domestic sphere.

\section{References}

1. Marsh, R.J. (1996). Women in Russia and Ukraine. Cambridge: Cambridge Univ. Press.

2. Pearce, D. (1978, February). The Feminization of Poverty: Women, Work, and Welfare. Urban and Social Change Review, 30.

3. Rudnichenko, N. (2014). Being a woman in Ukraine. URL: http://www.wumag.kiev.ua/ index2.php?param=pgs20033/80

4. Tolstokorova, A. (2009). Multiple Marginalities: Gender dimension of rural poverty, unemployment and labour migration in Ukraine. FAO-IFAD-ILO Workshop Rome. URL: http://www.fao-ilo.org/

5. Gerasytmenko, G. (2012). Incorporating Gender to Poverty Alleviating Policy in Ukraine. Paper presented at XXII IPSA Congress Madrid.

6. Martsenyuk, T. (2016). Gender equality situation in Ukraine: challenges and opportunities. Gender Equality Policies and eu Integration - experience of Visegrad for EaP Countries, 203-225. 
7. International Labour Organization (2016). Social Security System of Ukraine in 2014-15 and Beyond Towards effective social protection. URL: http://www.ilo.org/wcmsp5/groups/public/---europe/--ro-geneva/---sro-budapest/documents/publication/wcms_504529.pdf

8. US Department of State (2007). Bureau of Democracy, Human Rights and Labor. URL: http://www.state.gov/j/drl/rls/hrrpt/2007/100590.htm

9. US Department of State (2000). Country Reports on Human Rights Practices Bureau of Democracy, Human Rights and Labor. URL: http://www.state.gov/j/drl/rls/hrrpt/2000/eur/854.htm

10. Grushetsky, A., Kharchenko, N. (2009). Poverty, Gender and Coping Strategies in Ukraine. In S. Mannila, S. Vesikansa (Eds.), Social Problems and Policies in Central and Eastern European Countries (pp. 64-77). National Institute for Health and Welfare.

11. Giddens, A. (1984). The Constitution of Society: Outline of the Theory of Structuration. University of California Press.

12. Beverley, J. (2013). Structration Theory. URL: https://www.britannica.com/topic/structurationtheory

13. Marx, K. (1977). Capital: A Critique of Political Economy. New York: Vintage Books, 1, 781-94.

14. Góra, M., Kula, G., Rokicka, M., Rohozynsky, O., Ruzik, A. (2008). Social security, labour market and restructuring: Current situation and expected outcomes of reforms. ESCIRRU Working Paper, 05, European Research Project Funded by the 6th Framework Programme and Managed by DIW Berlin. URL: http://www.diw.de/documents/publikationen/73/81769/diw_escirru0005.pdf

15. Chepurko, G. (2010). Gender Equality in the Labour Market in Ukraine. International Labour Office, ILO Decent Work Technical Support Team and Country Office for Central and Eastern Europe. Kyiv: ILO. URL: http://www.ilo.org/wcmsp5/groups/public/---europe/---ro-geneva/---sro-budapest/ documents/publication/wcms_167169.pdf

16. State Statistics Service of Ukraine (2015). Employment rate in 2015, by sex, age group and place of residence. URL: http://www.ukrstat.gov.ua/operativ/operativ2015/rp/eans/eans_e/rzn_rik15_e.htm

17. Butler, J. (2000). New Perspectives on Women Entrepreneurs. Information Age Publishing. ISBN 97819315767.

18. Gender Equality. United Nations Ukraine. URL: http://www.un.org.ua/en/resident-coordinatorsystem/gender-equality

19. State Statistics Service of Ukraine (2015). Economically active population in 2015 , by sex and place of residence. URL: http://www.ukrstat.gov.ua

20. State Statistics Service of Ukraine (2016). Employment rate in 2016, by sex, age group and place of residence. URL: http://www.ukrstat.gov.ua/operativ/operativ2016/rp/eans/eans_e/rzn_rik16_e.htm

21. State Statistics Service of Ukraine (2016). Average monthly wages and salaries of women and men by type of economic activity in 2016. URL: http://www.ukrstat.gov.ua

22. Report Analytical Research On Women's Participation In The Labour Force In Ukraine (2012). URL: http://www.idss.org.ua/monografii/2013_en_womens\%20participation.pdf

23. Gienger, V. (2016). Ukraine's 'Invisible Crisis': 1.5 Million Who Fled War With Russia. Pressures Place Welcome at Risk. United states Institute of Peace. URL: https://www.usip.org/ olivebranch/2015/11/23/ukraines-invisible-crisis-15-million-who-fled-war-russia

24. World Bank (2017). Ukraine Economic Update. URL: http://www.worldbank.org/en/country /ukraine/publication/economic-update-spring-2017

25. Oksamytna, S., Stukalo, S. (2012). Prestige of professions and occupations in the social space of the city. In V. Vorona, M. Sulga (Eds.), Ukrianian society 1992-2012. Status and change trends. Sociological Monitoring (pp. 429-436). Kyiv: Institute of Sociology NAS of Ukraine [in Ukrainian]

26. Martsenyuk, T., Grytsenko, G., Kvit, A. (2016). The "Invisible Battalion": Women in ATO Military Operations in Ukraine. Kyiv-Mohyla Law and Politics Journal, 2, 171-187.

27. United Nations Women (2014). Ukraine. URL: http://eca.unwomen.org/en/where-we-are/ukraine 
Nwaoduh E.O.

28. United Nations (1995). Fourth World Conference on Women Beijing, China - Action for Equality, Development and Peace. URL: http://www.un.org/womenwatch/daw/beijing/platform/poverty.htm

29. Skoryk, M., Strebkova, Yu., Matvienko, S., Kogut, A. (2013). Women's Participation in the Social and Political Life in Ukraine 2010-2012. URL: https://rm.coe.int/1680599099

30. Rudenko, M. (2014). Internally Displaced Persons and Gender Aspects. Part. 2. Report of the Ukrainian Women's and Non-Governmental Organisations Input at the UN Human Rights Council. Women's international league for peace and freedom. URL: http://wilpf.org/wp-content/uploads/ 2014/07/Report.pdf

31. Koriukalov, M. (2014). Latest Developments in the Field of Gender Equality \& Internal and External Barriers. Part. 9. Report of the Ukrainian Women's and Non-Governmental Organisations Input at the UN Human Rights Council. Women's international league for peace and freedom. URL: http://wilpf.org/

wp-content/uploads/2014/07/Report.pdf

32. Report of National System of Monitoring on internally displaced people (IDP) (2007). URL: http://www.iom.org.ua/sites/default/files/nms_report_march_2017_ukr_new.pdf

33. Grebmer, V., Bernstein, J., Waal, De A., Prasai, N., Yin, S., Yohannes, Yi. (2015). Global Hunger Index: Armed Conflict and the Challenges of Hunger. Intl Food Policy Res Inst.

34. Gander, C., Magdyuk, L. (2006). Ukraine Gender Equality Review, Ukraine Program CIDA. URL: http://ukrainejlf.typepad.com/ukraine_tracking_womens_o/files/ukraine_gender_equality_review.pdf

35. Bern-Klug, M.; Barnes, N.D. (January 1999). Income characteristics of rural older women and implications for health status.Journal of Women \& Aging. Taylor and Francis, 11 (1),doi:10.1300/J074v11n01_03

Received on 07.02.17 and updated on 12.06.17

Нваода E.O. кафедра соціальних структур та соціальних відносин, Київський національний університет імені Тараса Шевченка, вул. Володимирська, 60, Київ, 01033, e-mail: eberenwaoduh@gmail.com

ФЕМІНІЗАЦІЯ БІДНОСТІ В УКРАЇНІ: ПЕРЕДУМОВИ, ПРИЧИНИ ТА НАСЛІДКИ

Проаналізовано характер фемінізації бідності в Україні, розкрито іiі передумови, причини та наслідки. Фемінізація бідності полягає в тому, що жіноча стать $є$ більш уразливою до бідності, що зумовлено такими факторами, як гендерна нерівність при ухваленні рішень; ситуація на ринку праці, нерівність у доходах і роль жінок в українському суспільстві. У радянські часи в Україні жінки жили краще, оскільки кожен повинен був працювати. Незважаючи на те, що жінки були зайняті в державному секторі, вони також відповідали за ведення домашнього господарства. Ця подвійна функція спонукала їх працювати в державному секторі, оскільки це приносило гроші, на відміну від домашньої сфери, яка потребувала ресурсів і не оплачувалась. Через роки після розпаду СРСР відбулися зміни, які мали негативні наслідки для жінок у країні. Через труднощі та погіршення економічної ситуації, народження дітей і догляд за ними, внутрішні обов'язки вони страждають більше, ніж чоловіки. Деякі причини були визначені у таких підтемах: економічні/трудові відносини, політика/ухвалення рішень, склад сім’і/демографія та вибір/ставлення. Тоді як наслідки є такими: насильницький вихід 3 ринку праці, недостатнє харчування, недостатній доступ до належної медичної допомоги, низька участь в оскарженні виборчих позицій, невелика чисельність жінок на керівних посадах у державному та приватному секторах, особливо на великих підприємствах. Рекомендації містять більш ширшу участь жінок у політиці та їх прагнення до високих державних позицій, скорочення сегрегації на ринку праці шляхом забезпечення гендерного балансу, участь як чоловічих, так i жіночих партнерів у внутрішній діяльності організації, підвищення заробітної плати тощо.

Ключові слова: фемінізація бідності, соціальна ізоляція, гендерна нерівність, сегрегація. 
Нваода Э.О. кафедра социальных структур и социальных отношений, Киевский национальный университет имени Тараса Шевченко, ул. Владимирская, 60, Киев, 01033, е-mail: eberenwaoduh@gmail.com

ФЕМИНИЗАЦИЯ БЕДНОСТИ В УКРАИНЕ: ПРЕДПОСЫЛКИ, ПРИЧИНЫ И ПОСЛЕДСТВИЯ

Проанализирован характер феминизации бедности в Украине, раскрыты ее предпосылки, причины и последствия. Феминизация бедности заключается в том, что женский пол более уязвим к бедности, что обусловлено такими факторами, как гендерное неравенство при принятии решений; ситуация на рынке труда, неравенство в доходах и роль женщин в украинском обществе. В советское время в Украине женщины жили лучше, поскольку каждый должен был работать. Несмотря на то, что женщины были заняты в государственном секторе, они также отвечали за ведение домашнего хозяйства. Эта двойная функция побуждала их работать в государственном секторе, поскольку это приносило деньги, в отличие от домашней сферы, которая требовала ресурсов и не оплачивалась. Спустя годы после распада СССР произошли изменения, которые имели негативные последствия для женщин в стране. Из-за сложностей и ухудшения экономической ситуации, рождения детей и ухода за ними, внутренних обязанностей они страдают больше мужчин. Некоторые причины были определены в следующих подтемах: экономические/трудовые отношения, политика/принятие решений, состав семьи/демография и выбор/отношение. В то время как последствия следующие: насильственный выход из рынка труда, недостаточное питание, недостаточный доступ к надлежащей медицинской помощи, низкое участие в оспаривании избирательных позиций, небольшая численность женщин на руководящих должностях в государственном и частном секторах, особенно на крупных предприятиях. Рекомендации включают более широкое участие женщин в политике и их стремление к высоким государственным позициям, сокращение сегрегации на рынке труда путем обеспечения гендерного баланса, участие как мужских, так и женских партнеров во внутренней деятельности организации, повышение заработной платы и т. п.

Ключевые слова: феминизация бедности, социальная изоляция, гендерное неравенство, сегрегация. 